\title{
Effect of upwelling pulses on excess carbohydrate synthesis as deduced from nutrient, carbon dioxide and oxygen profiles
}

\author{
F. Fraga ${ }^{1, *}$, A. F. Ríos ${ }^{1}$, F. F. Pérez ${ }^{1}$, M. Estrada ${ }^{2}$, C. Marrasé ${ }^{2}$ \\ ${ }^{1}$ Instituto de Investigacions Mariñas, CSIC, C/Eduardo Cabello 6, 36208 Vigo, Spain \\ ${ }^{2}$ Institut de Ciencies del Mar, CSIC, Paseig Joan de Borbó s/n, 08039 Barcelona, Spain
}

\begin{abstract}
The coupling between upwelling intensity off the NW lberian coast and differential carbohydrate synthesis and utilisation in the water column has been investigated using the conservative chemical parameters ' $\mathrm{NO}$ ', ' $\mathrm{CO}$ ' and ' $\mathrm{NCO}$ '. Differences between the observed vertical distribution of 'NO' and ' $\mathrm{CO}$ ' and that expected from Redfield stoichiometry indicate that an excess of carbohydrate synthesis occurs in the surface layer when nutrients become depleted during upwelling relaxation periods. Excess carbohydrate synthesised in upper layers is consumed at subsurface levels. This consumption can be attributed to the presence of autotrophic migratory organisms like the photosynthetic ciliate Mesodinium rubrum and several dinoflagellates which produce carbohydrates in the upper, well illuminated layers and take up nutrients in the subphotic zone. Conversely, situations of intense upwelling are associated with production of organic matter following the Redfield ratio and with a decrease in carbohydrate synthesis. Deviations from Redfield stoichiometry found in other marine areas could be explained by processes comparable to those occurring in the NW Iberian upwelling, suggesting that vertical migration by photosynthetic organisms may play a greater role in the vertical transport of nitrogen and carbon than generally recognized.
\end{abstract}

KEY WORDS: Upwelling $\cdot$ Carbohydrate $\cdot$ Redfield ratio

\section{INTRODUCTION}

Vertical advection of nutrients supports high population densities of phytoplankton in coastal upwelling areas. However, the structure and function of these populations fluctuate at a wide range of time scales in response to changes of the upwelling intensity and associated physical characteristics (Estrada \& Blasco 1979, Figueiras \& Ríos 1993, Kudela et al. 1997). Variability of upwelling intensity over a timescale of several days, typically associated with fluctuations in wind stress, is characteristic of all major upwelling areas. The alternation of periods of strong upwelling (or 'events'), which introduce cold and nutrient-rich waters from deep layers into the upper euphotic zone, and

•E-mail: ffraga@iim.csic.es periods of relaxation affects both the temporal and spatial variability of the upwelling ecosystem. During relaxation periods, exhaustion of nutrients in the euphotic zone may favour the development of phytoplankton forms able to migrate vertically and to take advantage of the nutrient content in subsurface waters (Raven \& Richardson 1984, Cullen 1985, Cullen et al. 1985, Villarino et al. 1995). This behaviour is shown by many dinoflagellates and other motile forms, like the autotrophic ciliate Mesodinium rubrum. These organisms are typical components of the upwelling community (Smith \& Barber 1979, Estrada \& Blasco 1985) and may develop dense populations reaching the category of red tides. During the day, migratory dinoflagellates remain in the euphotic zone and synthesise mainly carbohydrates, due to a lack of $\mathrm{N}$ and $\mathrm{P}$ for building other compounds. During the night, the organisms descend 
to the nutricline, in the subphotic zone, and synthesise proteins and other necessary compounds, using part of the carbohydrates produced and stored during the day both as an energy source and as a supplier of carbon for biosynthesis (Cullen 1985). M. rubrum presents a very active vertical migration (Wilkerson \& Grunseich 1990, Passow 1991) and probably uses the same strategy to capture nutrients when these disappear from the euphotic zone. In addition, recent studies have shown that even non-motile organisms, like Rhizosolenia sp. and other large diatoms, may accumulate carbohydrates in upper, nutrient-poor water layers; these may be used to regulate their buoyancy to sink down into the nutrient-rich subphotic zone (Villareal et al. 1993, 1996, 1999, Villareal \& Carpenter 1994, Richardson et al. 1996). Richardson \& Cullen (1995) observed that Thalassiosira weissflogii showed a similar behaviour in cultures.

Due to migration, as described above, the synthesis of carbohydrates in the nutrient-exhausted euphotic zone produces an increase of oxygen and a utilisation of $\mathrm{CO}_{2}$ without uptake of $\mathrm{NO}_{3}{ }^{-}$and $\mathrm{HPO}_{4}{ }^{2-}$. Conversely, in the nutrient-rich subphotic zone, $\mathrm{NO}_{3}{ }^{-}$and $\mathrm{HPO}_{4}{ }^{2-}$ are used up without equivalent oxygen production and $\mathrm{CO}_{2}$ utilisation. Fraga et al. (1992) modelled this differential synthesis using the following stoichiometric scheme:

Euphotic layer

$$
\begin{aligned}
149 \mathrm{HCO}_{3}^{-} & +149 \mathrm{H}_{2} \mathrm{O} \\
\rightarrow & 149\left(\mathrm{CH}_{2} \mathrm{O}\right)+149 \mathrm{O}_{2}+149 \mathrm{OH}^{-}
\end{aligned}
$$

Subphotic layer

$$
\begin{aligned}
& 149\left(\mathrm{CH}_{2} \mathrm{O}\right)+16 \mathrm{NO}_{3}{ }^{-}+\mathrm{HPO}_{4}{ }^{2-}+25 \mathrm{OH}^{-} \\
& \quad \rightarrow \mathrm{C}_{106} \mathrm{H}_{171} \mathrm{O}_{42} \mathrm{~N}_{16} \mathrm{P}+43 \mathrm{HCO}_{3}{ }^{-}+55 \mathrm{H}_{2} \mathrm{O}
\end{aligned}
$$

Considering a whole water column, with both euphotic and subphotic layers, the sum of processes (1) and (2) will fulfil the Redfield ratio according to the following stoichiometric equation:

$$
\begin{aligned}
& 106 \mathrm{HCO}_{3}{ }^{-}+16 \mathrm{NO}_{3}{ }^{-}+\mathrm{HPO}_{4}{ }^{2-}+94 \mathrm{H}_{2} \mathrm{O} \\
& \rightarrow \mathrm{C}_{106} \mathrm{H}_{171} \mathrm{O}_{42} \mathrm{~N}_{16} \mathrm{P}+149 \mathrm{O}_{2}+124 \mathrm{OH}^{-}
\end{aligned}
$$

However, as a consequence of the vertical separation between the production and consumption of carbohydrates, the relation of Redfield et al. (1963) will hold neither in the euphotic nor in the subphotic layers and the deviations from it will be stronger with increased synthesis and utilisation of carbohydrates. In summary, the processes described in (1) and (2) consume $141 \mathrm{~mol}$ of $\mathrm{CO}_{2}$ from the euphotic zone to convert $100 \mathrm{~mol}$ of carbon into biomass with a $\mathrm{C} / \mathrm{N}$ ratio of 6.6 and release $41 \mathrm{~mol}$ of $\mathrm{CO}_{2}$ in the subphotic zone. The $15 \mathrm{~mol}$ of nitrogen (100/6.6) needed for biomass synthesis are taken up from the subphotic zone. The combination of processes (1) and (2) has different implications than the deviations of the Redfield ratio described by Banse (1994) for a $6.1 \mathrm{~m}$ diameter plastic sphere, which were due to excess carbohydrate synthesis with respect to that of nitrogenated compounds, within the euphotic zone.

The spatial uncoupling between synthesis and consumption in the photic zone could be a scenario more widespread than previously recognized. This could explain the abnormal patterns of $\mathrm{C}$ and $\mathrm{N}$ utilisation found in marine areas like the Southern Benguela Upwelling System (Probyn et al. 1996), the subtropical waters of the NE Pacific (Emerson \& Hayward 1995) and the North Atlantic (Sambrotto et al. 1993).

The objective of this paper is to examine the coupling between relaxation periods after upwelling events off the NW Iberian coast and the deviations from Redfield ratios induced by differential carbohydrate synthesis in the water column.

\section{METHODS}

Data were collected during the cruise 'Galicia VIII', which took place between 13 July and 7 August 1984, on board the RV 'García del Cid'. During this survey, a transect perpendicular to the coast off the Ría de Pontevedra (Fig. 1) was sampled every $2 \mathrm{~d}$. This area, south of Cape Finisterre, is characterised by fluctuations of upwelling intensity with a mean period of $14 \pm 4$ d (Alvarez-Salgado et al. 1993). Further north, adjacent to Cape Finisterre, upwelling appears to be permanent during summer (Fraga 1981, Blanton et al. 1984).

Casts of 7 Niskin bottles of 1.7 1, supplied with 3 thermometers, 2 protected and 1 unprotected, were performed at the hydrographic stations shown in Fig. 1. Samples were taken every $10 \mathrm{~m}$ from the surface to the bottom. Salinity was measured with an induction salinometer 'Beckman RS-9'. Nitrate + nitrite and phosphate were determined by colorimetric methods, using a Technicon autoanalyser (Hansen \& Grassohoff 1983, Mouriño \& Fraga 1985). The technique has a shipboard precision for nitrate of $\pm 0.06 \mu \mathrm{mol} \mathrm{kg}{ }^{-1}$ (Castro \& Salgado 1996). $\mathrm{CO}_{2}$ was calculated using equations of the carbonic system (Mehrbach et al. 1973, Weis 1974) from $\mathrm{pH}$ and alkalinity determinations made by means of potentiometric techniques (Pérez \& Fraga 1987a,b). A 'Metrohm E-510' pH meter with an Orion 81-04 electrode calibrated with 7.413 NBS buffer was used to determine $\mathrm{pH}$. The shipboard precision of the method is $\pm 0.002 \mathrm{pH}$ (Ríos \& Rosón 1996). An accuracy of \pm 0.004 has been estimated using samples of Certified Reference Material (CRMs) provided by Dr Dickson at the University of California (Ríos \& Rellán 1998). An 


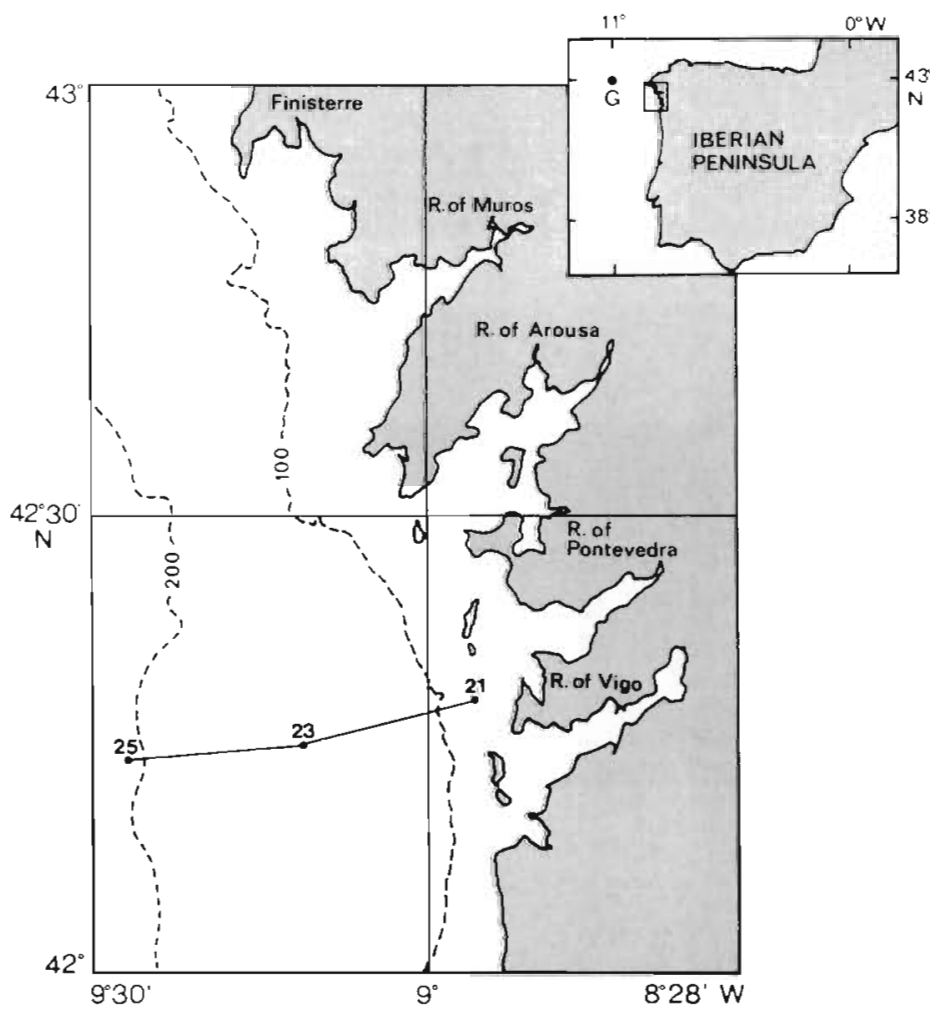

Fig. 1. Position of the stations referred to in this work. Point $G$ in the upper inset indicates the position for which geostrophic wind was calculated

automatic potentiometric titrator 'Metrohm' was used to measure alkalinity with $\mathrm{HCl}$ to a final $\mathrm{pH}$ of 4.44 . This method of alkalinity determination has a precision of $0.1 \%$ (Pérez \& Fraga 1987b), and the accuracy of $1.4 \mu \mathrm{mol} \mathrm{kg} \mathrm{kg}^{-1}$ was estimated from cross-calculation with measured CRMs (Ríos \& Rellán 1998). The precision and accuracy of $\mathrm{pH}$ and alkalinity translate to $\pm 3 \mu \mathrm{mol} \mathrm{kg} \mathrm{kg}^{-1}$ for $\mathrm{CO}_{2}$ measurements. Dissolved oxygen was analysed by the Winkler method using an automatic titration system 'Metrohm $670^{\prime}$ with a platinum electrode. The precision of this method is

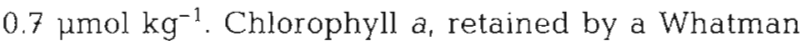
GF/C filter, was extracted with $90 \%$ acetone and the fluorescence of the extract measured using a Turner fluorometer following the technique of Strickland \& Parsons (1968). GF/C filters have a larger nominal pore size $(1.2 \mu \mathrm{m})$ than $\mathrm{GF} / \mathrm{F}$ filters (nominal pore size $0.7 \mu \mathrm{m}$ ) which are generally used nowadays. However, given the relatively high chlorophyll concentrations found in our study and the probable dominance of large cells, it is unlikely that the use of GF/C filters resulted in any significant chlorophyll a underestimation. Recent experiments carried out in the Ría of Vigo (X A Morán pers. comm.) with water of similar chlorophyll concentration did not show any significant differ- ences between the amount of chlorophyll retained by GF/C or GF/F filters. Chlorophyll concentrations without correction of phaeopigments were calculated according to the method of Yentsch \& Menzel (1963). The basic data from the cruise are reported in Mourino et al. (1985).

Phytoplankton samples were taken between 15 and 27 July, at $10 \mathrm{~m}$ intervals between the surface and $30 \mathrm{~m}$ depth. Sampling times varied for each station. Subsamples of $120 \mathrm{ml}$ of water were fixed with concentrated Lugol's solution, without acetic acid, and stored in Pyrex bottles. Phytoplankton composition was examined by means of the inverted microscope technique, after sedimentation in composite $100 \mathrm{ml}$ chambers. One transect of the chamber (approximately $1 \mathrm{ml}$ of sample) was observed at $500 \times$ to enumerate the smaller organisms and the whole chamber bottom was scanned to enumerate the larger forms. Cells of intermediate size were counted along an additional transect at $125 x$.

Upwelling index values used in this work were taken from Lavín et al. (1990). They were obtained from geostrophic wind calculation (Bakun 1973) for a point $\mathrm{G}$ located at $43^{\circ} \mathrm{N}, 11^{\circ} \mathrm{W}$, as indicated in the inset of Fig. 1.

In order to represent quantitatively the stoichiometric deviations from the Redfield ratio, Broecker's ' $\mathrm{CO}$ ' and 'NO' parameters (Broecker 1974) and the 'NCO' parameter proposed by Fraga et al. (1992) were used.

' $\mathrm{CO}$ ' and ' $\mathrm{NO}$ ' can be defined as:

$$
\begin{array}{lll}
{ }^{\prime} \mathrm{CO}=\mathrm{O}_{2}+R_{\mathrm{C}} \cdot \mathrm{CO}_{2} & R_{\mathrm{C}}=-\Delta \mathrm{O}_{2} / \Delta \mathrm{CO}_{2} & R_{\mathrm{C}}=1.41 \\
\mathrm{NO}^{\prime}=\mathrm{O}_{2}+R_{\mathrm{N}} \cdot \mathrm{NO}_{3}{ }^{-} & R_{\mathrm{N}}=-\Delta \mathrm{O}_{2} / \Delta \mathrm{NO}_{3}{ }^{-} & R_{\mathrm{N}}=9.3
\end{array}
$$

These parameters are related to the preformed nutrients $\left(\mathrm{CO}_{2}{ }^{\circ}\right.$ and $\left.\mathrm{NO}_{3}{ }^{\circ}\right)$, defined as the nutrient concentrations at the moment of water mass formation in winter, by the expressions:

$$
\mathrm{CO}^{\prime}=\mathrm{O}_{2 \mathrm{sat}}+R_{\mathrm{C}} \cdot \mathrm{CO}_{2}{ }^{\circ} \text { and } \mathrm{NO}^{\prime}=\mathrm{O}_{2 \mathrm{at}}+R_{\mathrm{N}} \cdot \mathrm{NO}_{3}{ }^{\circ}
$$

where $\mathrm{O}_{25 a t}$ indicates saturating oxygen concentration. The values of $R_{\mathrm{C}}$ and $R_{\mathrm{N}}$ correspond to the ratios obtained by Fraga et al. (1998).

If biochemical transformations follow Redfield stoichiometry, the parameters ' $\mathrm{CO}$ ' and ' $\mathrm{NO}$ ' remain constant during photosynthesis or remineralization of organic matter. However, if there is carbohydrate synthesis in excess of Redfield's stoichiometry, 'NO' increases at the same time that ' $\mathrm{CO}$ ' decreases, indicating a deviation from Redfield ratios. An alkalinity (A) correction was applied to the ' $\mathrm{CO}$ ' parameter $\left(=\mathrm{O}_{2}+R_{\mathrm{C}}\left[\mathrm{CO}_{2}-1 / 2\left(\mathrm{~A}+\mathrm{NO}_{3}\right)\right]\right)$, in order to make it independent from precipitation or dissolution of $\mathrm{CaCO}_{3}$ due to biological activity (Broecker \& Peng 1982, Takahashi et al. 1985). 
The definition of ' $N C O$ ' is:

$$
' \mathrm{NCO}^{\prime}=\mathrm{O}_{2}+\mathrm{CO}_{2}+R_{\mathrm{N}}\left(1-1 / \mathrm{R}_{\mathrm{C}}\right) \mathrm{NO}_{3}
$$

Fraga et al. (1992), Ríos et al. (1998). This parameter is independent of the fulfilment of Redfield's ratio concerning carbohydrate synthesis; like the other Broecker's parameters, it varies with the exchange of oxygen with the atmosphere. A deviation to lower values at the surface is a quantitative measure of oxygen loss to the atmosphere. During the sampling period, the mean oxygen loss estimated from the ' $\mathrm{NCO}$ ' profiles was $38 \pm 14 \mu \mathrm{mol}$ $\mathrm{kg}^{-1}$. In estimates using gas transfer coefficients given by Kester (1975), surface oxygen concentrations and wind speed gave a mean value of $48 \mathrm{mmol} \mathrm{m} \mathrm{m}^{-2} \mathrm{~d}^{-1}$. equivalent to $40 \mathrm{\mu mol} \mathrm{kg}^{-1}$, for the photic layer. The correlation between estimated oxygen losses to the atmosphere and negative anomalies of ' $N C O$ ' was highly significant $\left(\mathrm{r}^{2}=0.72, \mathrm{n}=10\right)$. In any case, according to these calculations, mean oxygen losses to the atmosphere amounted to only $6 \%$ of the mean value of the oxygen anomaly caused by excess carbohydrate synthesis.

\section{RESULTS}

A representative illustration of the thermohaline structure during the studied period corresponding to 19 July is shown in Fig. 2. The upper limit of ENACW (Eastern North Atlantic Central Water) is marked by the salinity maximum (indicated by a broken line in the figure). This limit ranges from $40 \mathrm{~m}$ depth during active upwelling to $60 \mathrm{~m}$ depth after relaxation periods. The upper water layer is composed of ENACW heated by solar radiation and influenced by fresh water contribution $(<2.6 \%)$ from the Rías Bajas.

The thermohaline and chemical properties of the upper part of the upwelled ENACW were fairly constant during the observation period (Table 1 ). The seasonal increase in nutrient concentration due to mineralization of organic matter described by Álvarez-Salgado et al. $(1993,1997)$ takes place mainly at the end of summer (Fraga 1981).

The beginning of the studied period (Fig. 3) coincided with a phase of upwelling intensification which reached its maximum on $16 \mathrm{July}$ and was followed by a period of relaxation which lasted from 19 to 25 July. A small upwelling event on 27 July was again followed by a strong relaxation (minimum index value on 1 August) and a new upwelling intensification with a peak on 7 August.
The temporal evolution of nitrate and chlorophyll a concentrations (Fig. 4) showed a clear association with upwelling intensity. As can be seen in Fig. 4, upwelling intensity maxima on 16 and 27 July were followed by increased nitrate concentrations after a lag of about 2 d. Minimum nitrate concentrations were observed after the relaxation of 1 August. Chlorophyll maxima appeared in the upper water layers with a lag of 2 to $3 \mathrm{~d}$ after upwelling events. Chlorophyll maxima became deeper (24 to 27 July and 31 July to 2 August), during relaxation periods, following the deepening of the nitrate isopleths.

The patterns of variability of phytoplankton biomass and composition reflected those of the physico-chemi-

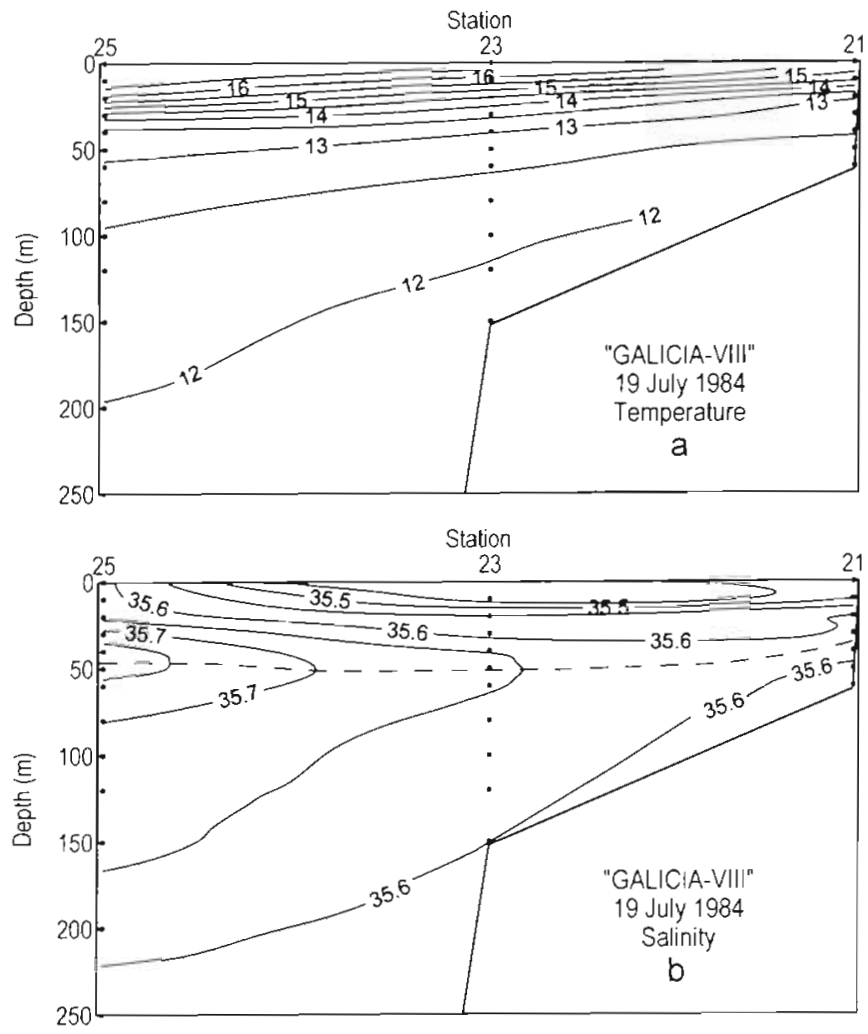

Fig. 2. Vertical profiles of (a) temperature and (b) salinity corresponding to 19 July for the transect between Stns 21 and 25 of Fig. 1. The broken line indicates the upper limit of the ENACW (Eastern North Atlantic Central Water) 


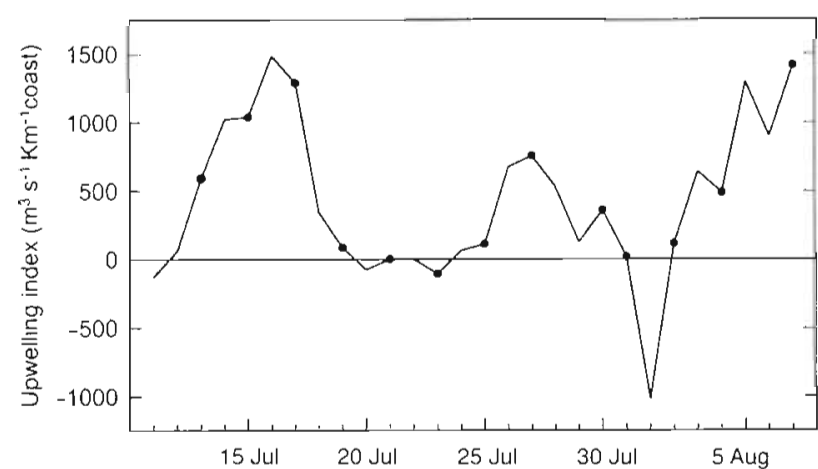

Fig. 3. Daily upwelling index off Cape Finisterre, taken from Lavín et al. (1990) from 11 July to 7 August 1984. • : dates on which Stns 21 to 25 were sampled

cal variables. Diatom abundances (Fig. 5) increased markedly in surface waters following the upwelling event of 16 July and reached a maximum dominated by Chaetoceros spp. and Leptocylindrus minimus on 19 July. Their populations decreased during the first relaxation on 21 July, but increased again with a new pulse of upwelling. On 24 July, a diatom maximum dominated by $L$. minimus and small centric diatoms, which appeared to be in a rather senescent state, was present at the surface; however, due to the small cell sizes of these taxa and the probably low pigment content of the senescent diatoms, these high numbers were not strongly reflected in the chlorophyll distribution. The subsurface chlorophyll maximum which appeared during the first relaxation was associated with high population densities of Mesodinium rubrum, a photosynthetic ciliate with symbiotic chloroplasts, and several dinoflagellate taxa (Fig. 5). M. rubrum and the dinoflagellates are motile organisms and present migratory behaviour (Villarino et al. 1995); therefore, their vertical distribution may be dependent on the time of sampling (see Mouriño et al. 1985) and could have been different at other moments of the diel cycle.

The vertical profiles of $\mathrm{O}_{2}, \mathrm{NO}_{3}$ and $\mathrm{CO}_{2}$ recorded on 17 July and 2 August can be taken as representative of the situations following maximum upwelling intensity on 16 July and strongest downwelling on 1 August (Fig. 6). We have represented the scales of $\mathrm{O}_{2}, \mathrm{CO}_{2}$ and $\mathrm{NO}_{3}$ variables following the classical Redfield ratio (149:106:16). In addition, the preformed values of $\mathrm{NO}_{3}{ }^{\circ}$

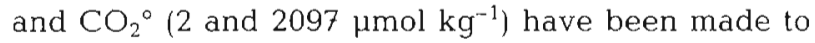
coincide with the saturating oxygen concentration (259 $\mu \mathrm{mol} \mathrm{kg}^{-1}$ ). So, if the Redfield ratio holds, the vertical distributions of $\mathrm{NO}_{3}$ and $\mathrm{CO}_{2}$ appear superimposed, and are the mirror image of the vertical distribution of oxygen with respect to the line representing oxygen saturation.

As can be seen in Fig. 6a (17 July), 1 d after maximum upwelling intensity the vertical profiles of $\mathrm{O}_{2}$,
$\mathrm{NO}_{3}$ and $\mathrm{CO}_{2}$ followed the pattern of synthesis-remineralisation expected from the Redfield ratio. There was utilisation of $\mathrm{CO}_{2}$ and $\mathrm{NO}_{3}$ by photosynthesis from $30 \mathrm{~m}$ depth up to the surface, while the remaining excess concentration of $\mathrm{NO}_{3}$ in surface was $0.46 \mathrm{\mu mol}$ $\mathrm{kg}^{-1}$. On the contrary, on 2 August, after the downwelling event, with the $1 \%$ light level at $24 \mathrm{~m}, \mathrm{NO}_{3}$ was completely exhausted between 0 and $20 \mathrm{~m}$, but this coexisted with high $\mathrm{O}_{2}$ production and $\mathrm{CO}_{2}$ consumption (Fig. 6b). The vertical profiles of the 3 variables were not symmetrical as in the previous case (17 July), in spite of having taken into account the losses of oxygen to the atmosphere. The observed $\Delta \mathrm{O}_{2}: \Delta \mathrm{CO}_{2}=1$ ratio, lower than Redfield's (1.41), was indicative of carbohydrate synthesis (Eq. 1). There was no photosynthesis between 30 and $40 \mathrm{~m}$; however $\mathrm{NO}_{3}$ was utilised without production of $\mathrm{O}_{2}$ or the corresponding consumption of $\mathrm{CO}_{2}$, which even showed a slight increase at $30 \mathrm{~m}$, as could be expected from Eq. (2). The Redfield ratio did not hold for either the photic or aphotic layers.

The estimated parameters ' $\mathrm{NO}$ ' and ' $\mathrm{CO}$ ' showed opposite values indicating a deviation from the Redfield ratio. A ' $\mathrm{NO}$ ' increase and a ' $\mathrm{CO}$ ' decrease in the vertical profiles between 0 and $20 \mathrm{~m}$ (Fig. 7) indicate carbohydrate synthesis. In the subphotic layer (about 20 to $40 \mathrm{~m}$ ), a ' $N O$ ' decrease and a 'CO' increase reflect nutrient assimilation at the expense of carbohydrate consumption.

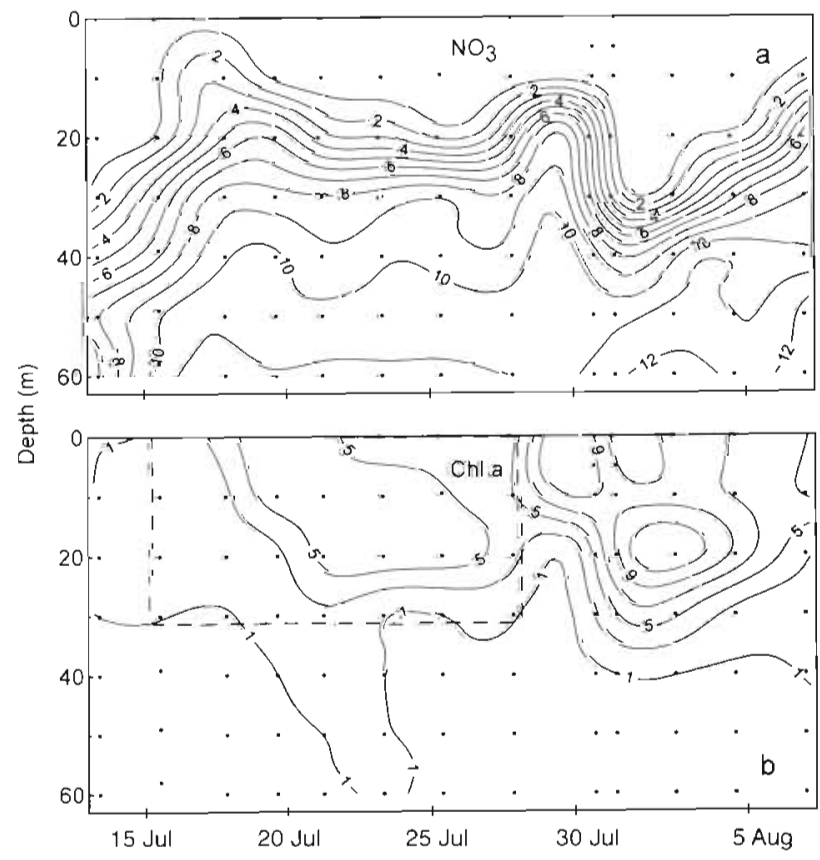

Fig. 4. Vertical distribution of (a) $\mathrm{NO}_{3}^{-}$in $\mu \mathrm{mol} \mathrm{kg}^{-1}$, (b) chlorophyl a in $\mu \mathrm{g} \mathrm{kg}^{-1}$ of sea water, at $\operatorname{Stn} 21$, from 13 July to 7 August. The square in (b) indicates the zone where organisms were identified and phytoplankton cells counted (Fig. 5) 

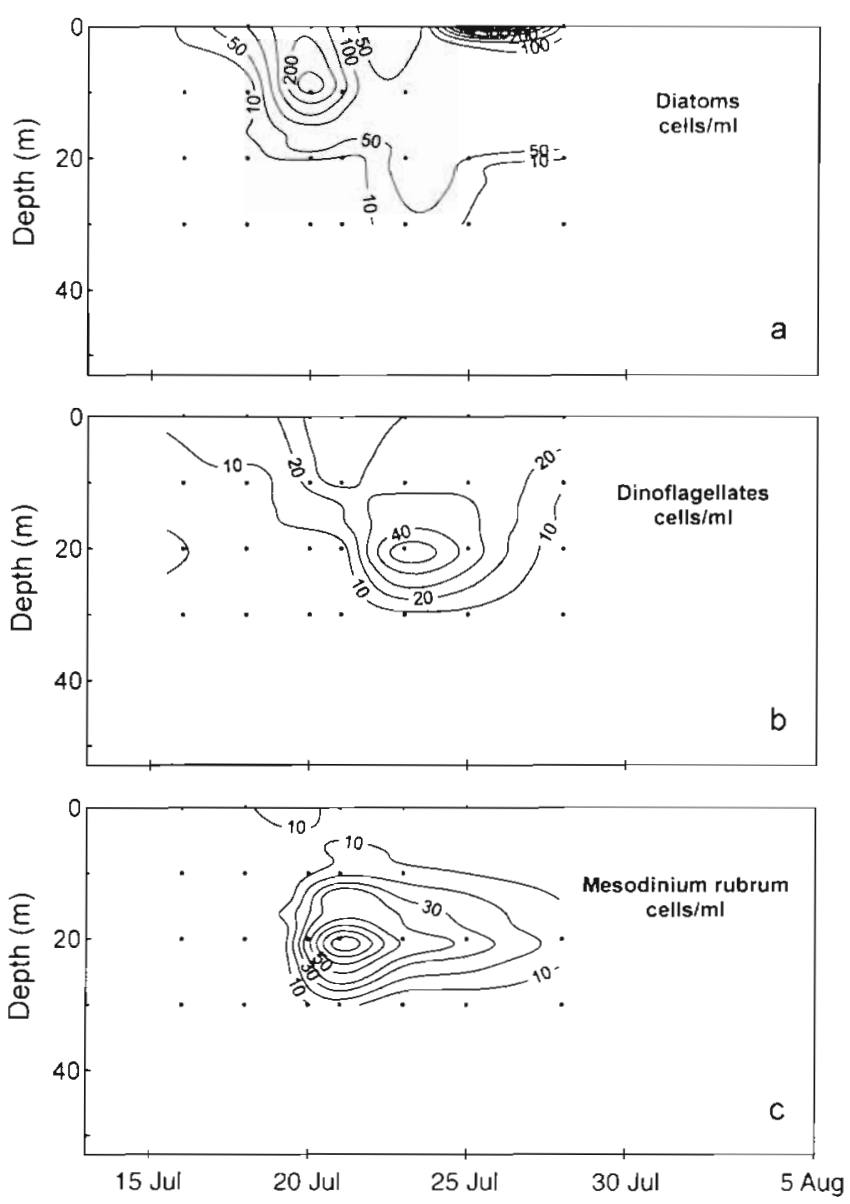

Fig. 5. Vertical distribution of the population density (cells $\mathrm{m}^{-1}$ ) of (a) diatoms, (b) dinoflagellates and (c) the photosynthetic ciliate Mesodinium rubrum, at Stn 21, from 15 to 27 July

The temporal evolution of ' $\mathrm{NO}$ ' and ' $\mathrm{CO}$ ' (Fig. 7) showed a clear relationship with upwelling relaxation, mediated by the lack of nutrient inputs. There were deviations on $13 \mathrm{July}$, after a relaxation previous to the beginning of our sampling. The subsequent upwelling intensification produced a decrease of the anomalies, which disappeared completely after the upwelling maximum on 17 July. The relaxation period between 20 and 25 July produced an increment of anomalies which was temporarily attenuated by the weak upwelling pulse on 26 to 27 July. The intensification of upwelling after 4 August induced a decrease in anomalies followed by their complete disappearance.

The relationship between vertical nutrient anomalies and upwelling intensity can be studied after quantification of the vertical carbohydrate transport, which may be estimated from the excess carbohydrate synthesised in the euphotic zone and the carbohydrate consumption in the subphotic layers. Excess carbohydrate synthesis can be calculated from the vertical integration of $\Delta^{\prime} \mathrm{NO}^{\prime}-\Delta^{\prime} \mathrm{CO}^{\prime}$ in the photic layer, while excess used carbohydrate can be obtained from the vertical integration of $\Delta^{\prime} \mathrm{NO}^{\prime}-\Delta^{\prime} \mathrm{CO}^{\prime}$ (Fraga et al. 1992) in the subphotic zone. $\Delta^{\prime} \mathrm{NO}^{\prime}$ ' is the difference between the 'NO' value at each depth and a ' $N O$ ' reference value, which is considered to be that of the superior level of the North Atlantic Central Water (NACW). $\triangle^{\prime} \mathrm{CO}$ is calculated in a similar way. To express carbohydrates (Cbh) in carbon units, $\Delta^{\prime} \mathrm{NO}^{\prime}-\Delta^{\prime} \mathrm{CO}^{\prime}$ is divided by the stoichiometric ratio $\left(R_{\mathrm{C}}=1.41\right)$.

Due to the lag between the phytoplankton response and the upwelling and relaxation events, carbohydrate transport was correlated with upwelling intensity (Fig. 8) $2 \mathrm{~d}$ before $\left(\mathrm{r}^{2}=0.72, \mathrm{n}=13\right)$. During the relaxation periods of 21 to 25 July and 30 to 31 July, carbohydrates increased rapidly. On the contrary, upwelling intensification between 13 to 17 July and 2 to 7 August (Fig. 8) was associated with a decrease in the carbohydrate excess and even negative vertical transport values. These negative transport values corresponded to situations of intense upwelling in which subsurface waters, with a 'NO' deficit due to carbohydrate consumption, reached the surface layers.

The dominant taxa in the subphotic layer during the relaxation period (Fig. 5) were Mesodinium rubrum and several dinoflagellates, motile and capable of migrating within the water column. If phytoplankton were responsible for the excess carbohydrate consumption and corresponding differential synthesis of organic matter, a significant correlation would be expected between vertically integrated chlorophyll and excess carbohydrate used in the subphotic layer. This was indeed the case $\left(\mathrm{r}^{2}=0.7, \mathrm{n}=11\right)$, as can be seen in Fig. 9, in which the samplings of 15 and 17 July, corresponding to the peak of upwelling intensity, have been excluded. The relationship shown in Fig. 9 provides evidence of the usefulness of the ' $\mathrm{NO}$ ' and ' $\mathrm{CO}$ ' parameters to estimate synthesis, transport and utilisation of carbohydrates and the usefulness of ' $\mathrm{NCO}$ ' to calculate the cumulative $\mathrm{O}_{2}$ loss to the atmosphere.

\section{DISCUSSION}

The results of this study show that during upwelling relaxation, when nutrients become exhausted at the surface, production of carbohydrates by phytoplankton leads to deviations from Redfield stoichiometry. This is a process in which the amount of carbohydrates does not represent the synthesis actually taking place in the photic zone at a particular moment, but the cumulative amount of carbohydrate transported from the photic to the subphotic zone during all the relaxation period. Mesodinium rubrum has been shown to be able to take up amino acids and dissolved organic carbon, although the importance of this ability for its overall carbon bud- 
(a) 17 July

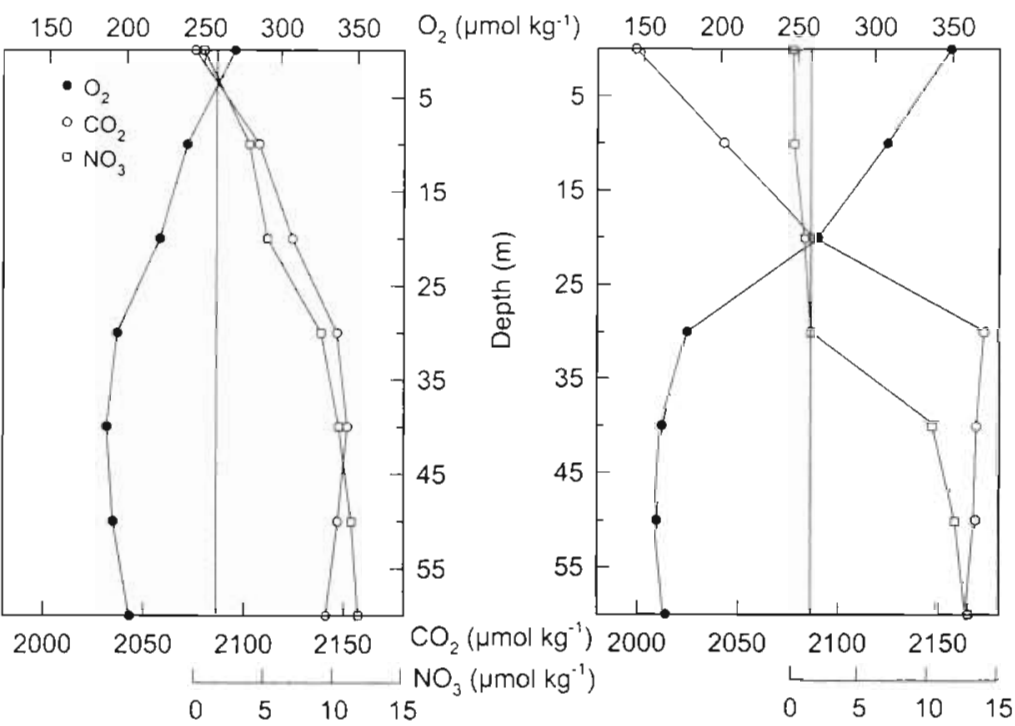

Fig. 6. Vertical distribution of $\mathrm{O}_{2}, \mathrm{CO}_{2}$ and $\mathrm{NO}_{3}{ }^{-}$at $\mathrm{Stn} 21$, (a) in conditions of intense upwelling on 17 July, and (b) after a relaxation of upwelling on 2 August. The relative magnitude of the unit for each scale is proportional to the inverse of the Redfield ratio. The preformed values of each parameter $\left(\mathrm{O}_{2 \text { sal }}, \mathrm{CO}_{2}^{\circ}\right.$, and $\mathrm{NO}_{3}^{\circ}$, Table 1$)$ have been made to coincide with the vertical line at the centre of the figure
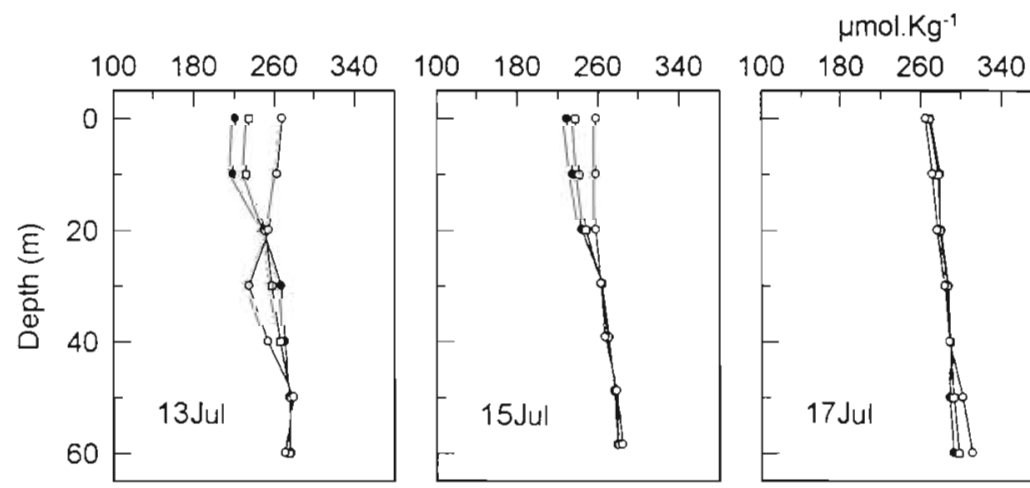

100

$\begin{array}{llll}180 & 260 & 340 & 100\end{array}$

180260

340
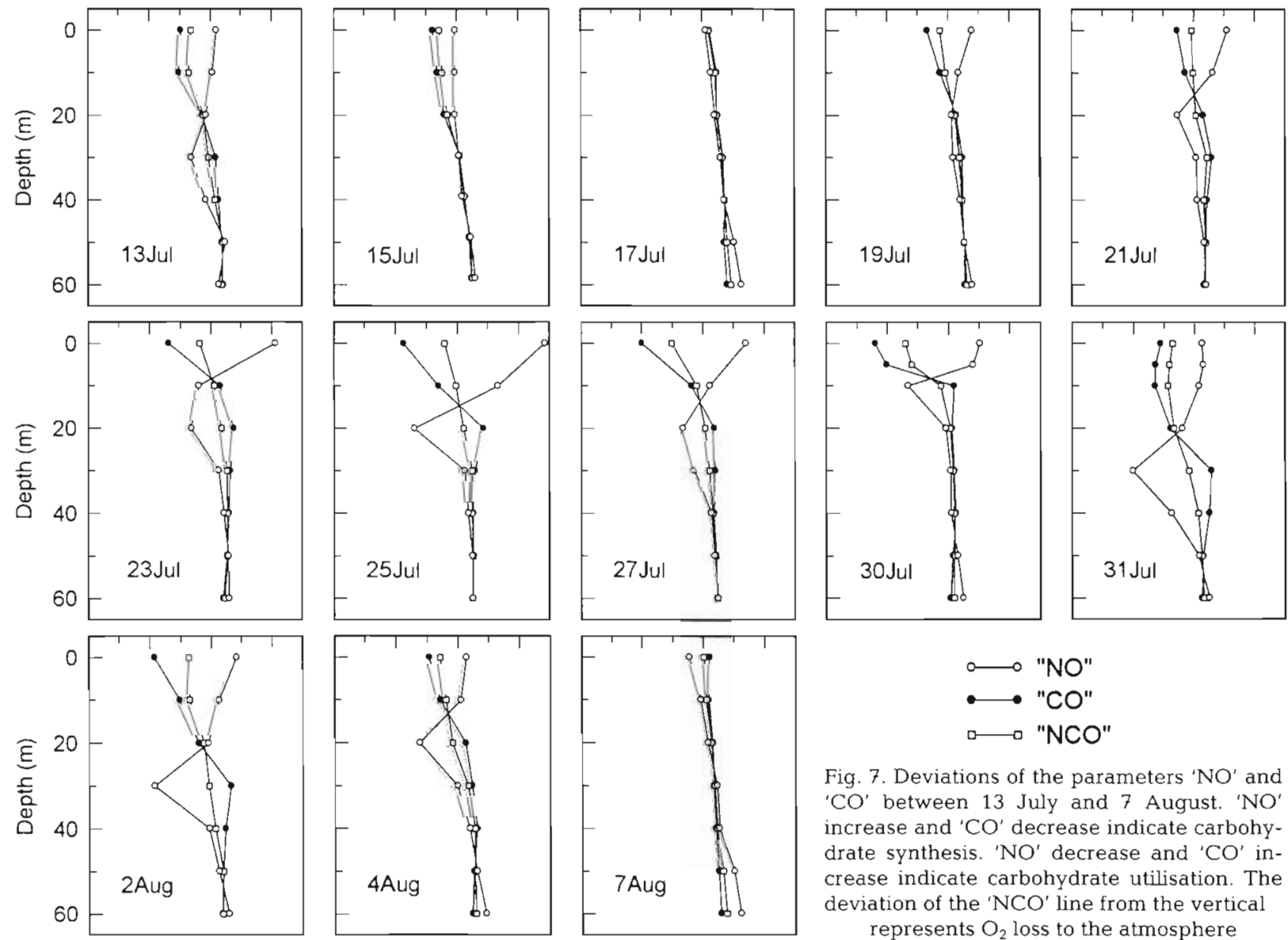

Fig. 7. Deviations of the parameters 'NO' and ' $\mathrm{CO}$ ' between $13 \mathrm{July}$ and 7 August. 'NO' increase and ' $\mathrm{CO}$ ' decrease indicate carbohydrate synthesis. ' $\mathrm{NO}$ ' decrease and ' $\mathrm{CO}$ ' increase indicate carbohydrate utilisation. The deviation of the ' $\mathrm{NCO}$ ' line from the vertical represents $\mathrm{O}_{2}$ loss to the atmosphere 


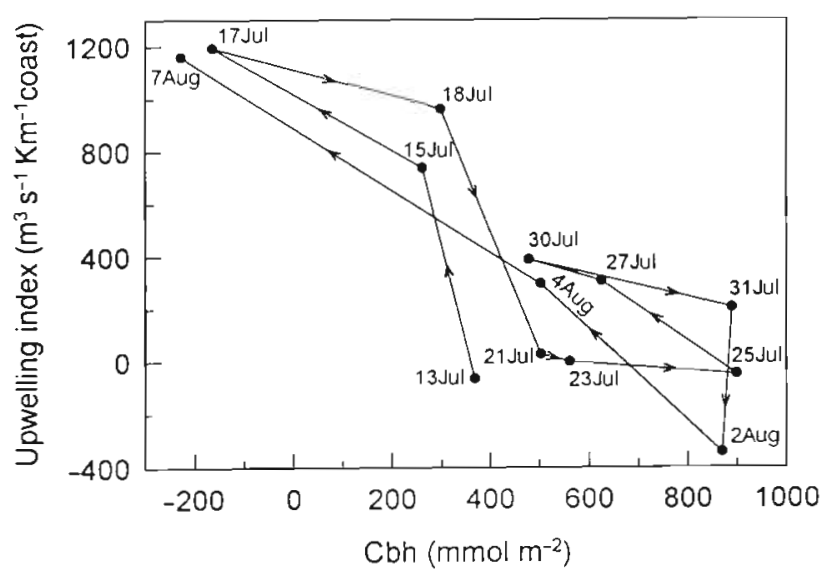

Fig. 8. Carbohydrates (Cbh) transported from the euphotic to the subphotic zone versus upwelling index. Cbh were calculated from ' $\mathrm{NO}$ ' and ' $\mathrm{CO}$ ' as explained in the text. The numbers indicate the sampling date and are linked sequentially, from 13 July to 7 August

get was unclear (Smith \& Barber 1979). Our interpretation of the data presented in this study has not been affected by this heterotrophic activity, because our calculation of carbohydrate synthesis is based on the loss of inorganic carbon in the photic zone, without nitrate assimilation, a process that can only be attributed to photosynthetic activity.

According to Villareal et al. (1996), $N$ limitation is a key factor in the regulation of the migratory behaviour of phytoplankton through its effect on carbohydrate metabolism. Moore \& Villareal (1996) showed that the buoyancy of different Rhizosolenia species in culture was inversely proportional to their carbohydrate content. These authors observed that $R$. formosa was able to take up nitrate during the night and that production and consumption of carbohydrates by this diatom was adequate to explain the buoyancy changes. Richardson et al. (1998) presented a numerical model of nutrient uptake and photosynthesis during migrations of Rhizosolenia and estimated that new primary production due to Rhizosolenia migrations in the tropical ocean represented up to $17 \%$ of the new production due to turbulent fluxes of nitrate. According to Villareal et al. (1999), $N$ transport by Rhizosolenia mats in the North Pacific central gyre could represent, on average, $20 \%$ of the turbulent nitrate flux. Dinoflagellates may use carbohydrates as a reserve of energy to allow nitrate uptake in the dark (Cullen 1985). Carbohydrates have also been shown to support dark protein synthesis in natural phytoplankton populations (Cuhel et al. 1984, Lancelot \& Mathot 1985).

Carbohydrate synthesis is affected very rapidly by changes in upwelling intensity, as can be seen in Fig. 8. Intensification of upwelling favourable winds
(Fig. 3) produces vertical advection of deep waters and introduces nutrients into the euphotic zone. In the presence of nutrients, dinoflagellates stop carbohydrate accumulation (Cullen 1985), and nutrient relationships adopt Redfield stoichiometry before the occurrence of any significant change in phytoplankton assemblages. These observations suggest that carbohydrates play an important role in the life strategy of vertical migrators and in the anomalies of the nutrient and oxygen distributions in the water column

Excess carbohydrate synthesis in the photic layer has also been described in embayments affected by coastal upwelling (Fraga et al. 1992), generating vertical transport of nitrogen and high $\Delta \mathrm{C}: \Delta \mathrm{N}$ relationships in surface layers. In a tropical upwelling ecosystem, Walsh (1996) described high $\triangle \mathrm{C}: \Delta N$ uptake ratios (from 10 to 28.6) when nitrate was exhausted from the surface layers. In this case, $\mathrm{N}_{2}$ fixation was the proposed mechanism to explain high $\mathrm{CO}_{2}$ consumption figures. This process can be disregarded on the Galician coast because the distribution of $\mathrm{PO}_{4} \mathrm{H}^{=}$was similar to that of $\mathrm{NO}_{3}{ }^{-}$. The correlation coefficient between both variables was $r^{2}=0.94(n=81)$, and the slope of the regression line of $\mathrm{PO}_{4} \mathrm{H}^{=}$on $\mathrm{NO}_{3}{ }^{-}$was 16.05 .

In the subtropical oligotrophic waters of the $\mathrm{NE}$ Pacific, layers of negative preformed nitrate appear to occur in the subphotic zone above the nutricline, and have been attributed to the occurrence of respiration without the stoichiometric component of nitrogen remineralisation (Emerson \& Hayward 1995). These authors have observed nitrate deficits amounting up to $5 \mu \mathrm{mol} \mathrm{kg}{ }^{-1}$ associated to the subphotic layer as negative preformed $\mathrm{NO}_{3}{ }^{\circ}$. In this study, the subsuperficial ' $N \mathrm{O}^{\prime}$ anomalies found at times of maximum relaxation

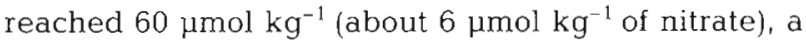
value comparable to those found by Emerson \& Hayward (1995). Pérez et al. (1986) found negative nitrate anomalies with slightly lower mean values $(2.5 \mu \mathrm{mol}$ $\mathrm{kg}^{-1}$ ) in the oligotrophic waters of the NW Mediterranean, just below the deep chlorophyll maximum (DCM), which is typically found during the stratification period and underlies a slightly shallower oxygen maximum (Estrada 1985, Estrada et al. 1993). Lewis et al. (1986), working in oligotrophic Atlantic waters, found that $1 / 3$ of the nitrate consumption took place at depths receiving $<1 \%$ of surface light. Subsurface chlorophyll maxima are ubiquitous in stratified waters and are due to the combination, in varying proportions, of increased phytoplankton abundances and higher chlorophyll content per cell due to photoacclimation (Cullen 1982, Estrada 1985). In some regions, like the frontal zones of the English Channel (Holligan 1978), the phytoplankton community of the DCM is dominated by 1 or a few species of migratory dinoflagellates. In more oligotrophic areas, like the Mediter- 
ranean, the phytoplankton assemblage of the DCM is very diverse, but may contain patches of high phytoplankton biomass dominated by diatom taxa like Chaetoceros, Thalassiosira and Rhizosolenia (Estrada 1991). The occurrence of negative nitrate anomalies in the subphotic zone in different regions and the observation that not only dinoflagellates and photosynthetic ciliates like Mesodinium, but also some diatoms like Rhizosolenia may vary their position in the water column suggest that the situation described here for the Galician upwelling could be widespread in other marine areas.

A high $\Delta \mathrm{CO}_{2}: \Delta \mathrm{NO}_{3}$ uptake ratio was observed by Sambrotto et al. (1993) in the North Atlantic, when exhaustion of nitrate after the spring bloom produced a similar situation to that described in the present study for upwelling relaxation. Sambrotto et al. (1993) proposed the synthesis of dissolved organic matter with a high $\mathrm{C}: \mathrm{N}$ ratio to explain their findings. However, an alternative mechanism could be the transport of nitrogen due to vertically migrating phytoplankton.

Diel patterns of nitrogen uptake were investigated by Probyn et al. (1993) in the Southern Benguela Upwelling System, by means of ${ }^{15} \mathrm{~N}$ uptake experiments. These authors found that $\mathrm{NO}_{3}$ consumption in the subphotic zone during the night was about $60 \%$ of the total for the whole water column near the coast, and tended to decrease offshore. On the other hand, the night:day nitrate consumption ratio increased with distance from the coast. These findings suggested that the contribution of dark nitrate uptake to new production increased with decreasing nutrient availability in the euphotic zone (Probyn et al. 1993). In the present study, nutrient and carbohydrate anomalies were also calculated at Stns 23 and 25 (Fig. 1) which were sam-

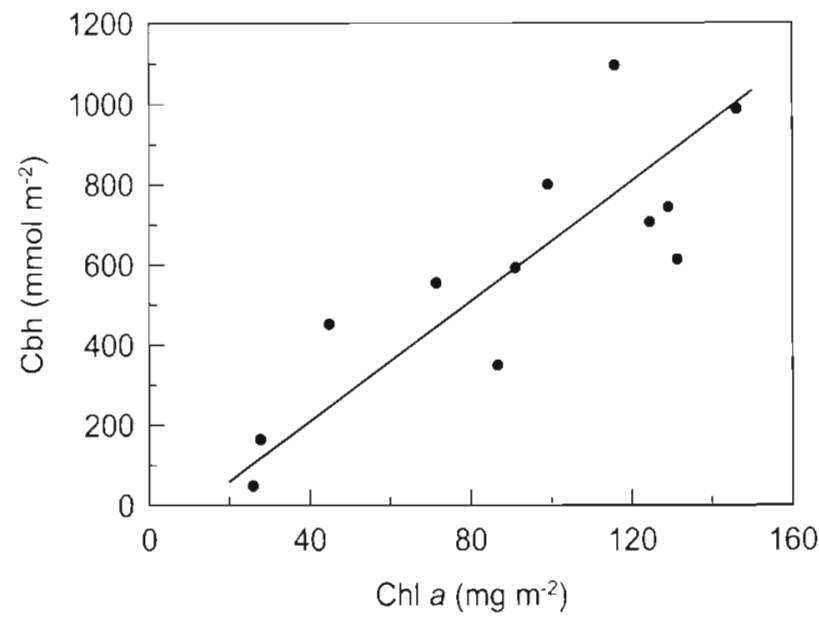

Fig. 9. Carbohydrate utilised in the subphotic layer in mmol m $\mathrm{m}^{-2}$ of carbon versus chlorophyll $a$ in $\mathrm{mg} \mathrm{m}^{-2}$ These are vertically integrated values for the subphotic zone pled on the same dates as Stn 21. As reported by Probyn et al. (1993), the intensity of the anomalies decreased seawards. At Stn 21, the nutricline was located at $15 \mathrm{~m}$ depth and carbohydrate utilisation in the subphotic layer was $100 \%$ of the synthesised carbohydrate in the photic layer. At Stn 23, the nutricline depth was $23 \mathrm{~m}$ and carbohydrate utilisation was $50 \%$. Further offshore, at Stn 25, the nutricline level was 38 $\mathrm{m}$ and carbohydrate utilisation was only $18 \%$. A likely explanation of these findings could be a decrease of nutrient utilization by migratory organisms with increasing nutricline depth, due to the longer travel distance for their migration.

This study has used Broecker's (1974) 'NO' and 'CO' parameters to show the biogeochemical implications of vertical carbohydrate transport in an ecosystem subjected to intermittent upwelling pulses. This vertical transport was mediated by migrating organisms with the ability to generate high $\Delta \mathrm{C}: \Delta N$ ratios due to excess carbohydrate synthesis in the euphotic layer during the day and nitrogen consumption in the subphotic layer during the night. Some of these characteristics have been observed in other aquatic systems, suggesting that vertical migration may play a greater role in the vertical transport of nitrogen and carbon than previously considered.

Some ecological and biogeochemical implications of deviations from Redfield stoichiometry have been outlined by Goldman et al. (1992) and Richardson \& Cullen (1995), who carried out culture experiments, and Villareal et al. (1999), who worked in the oligotrophic central North Pacific Ocean. We showed that uncoupling between photosynthesis and nutrient uptake can occur in an upwelling region. In the process described here, carbohydrate synthesis in the euphotic zone represents only a first step in the production of additional biomass. The synthesis of this biomass needs to be completed in the subphotic zone with the incorporation of the necessary nutrients. Thus, there is no deviation from Redfield stoichiometry when both euphotic and subphotic layers are considered as a whole, although the upwards flux of new nitrogen increases, as pointed out by Villareal et al. (1999). In addition, the uncoupling between photosynthesis and nutrient uptake reported here may have important biogeochemical implications due to its effect on the distribution of $\mathrm{CO}_{2}$ and on its exchanges between the sea surface and the atmosphere.

Acknowledgements. The preparation of this paper was supported by grant number CICYT MAR97-0660. The authors wish to thank all the participants in the 'Galicia VIII' cruise and the crew of the RV 'Garcia del Cid', as well as T Rellán for the management of the figures. 


\section{LITERATURE CITED}

Alvarez-Salgado XA, Rosón G, Pérez FF, Pazos Y (1993) Hydrographic variability off the Rías Baixas (NW Spain) during the upwelling season. Geophys Res 98: $14447-14455$

Alvarez-Salgado XA, Castro CG, Pérez FF, Fraga F (1997) Nutrient mineralization patterns in shelf waters of the Western Iberian upwelling. Cont Shelf Res 17:1247-1270

Bakun A (1973) Coastal upwelling indices, west coast of North America, 1946-1971. NOAA Tech Rep NMFS SSRF-671, US Dept of Commerce, Seattle, WA

Banse K (1994) Uptake of inorganic carbon and nitrate by marine plankton and the Redfield ratio. Global Biogeochem Cycles $8(1): 81-84$

Blanton JO, Atkinson LP, Castillejo FF, Lavín A (1984) Coastal upwelling off Rías Bajas, Galicia, Northwest Spain. I. Hydrographic studies. Rapp PV Réun Cons Int Explor Mer 183:79-90

Broecker WS (1974) 'NO': a conservative water-mass tracer. Earth Planet Sci Lett 23:100-107

Broecker WS, Peng TH (1982) Tracers in the sea. Columbia University, New York

Castro CG, Alvarez-Salgado XA (1996) Nutrient measurements. In: Recueil de données par Le Groupe CITHER-2, Vol 3. Laboratoire de Physique des Océans (96-02), Brest, p $29-48$

Cuhel RL, Ortner PB, Lean DRS (1984) Night synthesis of protein by algae. Limnol Oceanogr 29:731-744

Cullen JJ (1982) The deep chlorophyll maximum: comparing vertical profiles of chlorophyll $a$. Can J Fish Aquat Sci 39: $791-803$

Cullen JJ (1985) Diel vertical migration by dinoflagellates: roles of carbohydrate metabolism and behavioral flexibility. In: Rankin MA (ed) Migration: mechanisms and adaptative significance. Cont Mar Sci 27(Suppl):135-152

Cullen JJ, Zhu M, Davis RF, Pierson DC (1985) Vertical migration, carbohydrate synthesis and nocturnal nitrate uptake during growth of Heterocapsa niei in a laboratory water column. In: Anderson DM, White DA, Barden DG (eds) Toxic dinoflagellates. Elsevier Science Publishing Company, Inc, New York, p 189-194

Emerson S, Hayward TL (1995) Chemical tracers of biological processes in shallow waters of North Pacific: preformed nitrate distributions. J Mar Res 53:499-513

Estrada M (1985) Deep phytoplankton and chlorophyl maxima in the Western Mediterranean. In: Moraitou-Apotolopoulou M, Kiortsis V (eds) Mediterranean marine ecosystems. Plenum Press, New York, p 247-277

Estrada M (1991) Phytoplankton assemblages across a NW Mediterranean front: changes from winter mixing to summer stratification. In: Ros J, Prat N (eds) Homage to Ramón Margalef or why there is such pleasure in studying nature? Oecologia Aquat 10:157-185

Estrada M, Blasco D (1979) Two phases of the phytoplankton community in the Baja California upwelling. Limnol Oceanogr 24(6): 1065-1080

Estrada M. Blasco D (1985) Phytoplankton assemblages in coastal upwelling areas. In: Bas C, Margalef R, Rubies P (eds) Simposio Internacional sobre las areas de afloramiento mas importantes del Oeste Africano. Ins Inv Pesq CSIC, Barcelona, p 379-402

Estrada M Marrasé C, Latasa M, Berdalet E, Delgado M, Riera T (1993) Variability of deep chlorophyll maximum characteristics in the Northwestern Mediterranean. Mar Ecol Prog Ser 92:289-300

Figueiras FG, Ríos AF (1993) Phytoplankton succession, red tides, and the hydrographic regime in the Rias Bajas of Galicia. In: Smayda TJ, Shimizu Y (eds) Toxic marine phytoplankton. Elsevier Science Publisher, Amsterdam, p 239-244

Fraga F (1981) Upwelling off the Galician coast, Northwest Spain. In: Richards FA (ed) Coastal upwelling. American Geophysical Union, Washington, DC, p 176-182

Fraga F, Pérez FF, Figueiras FG, Ríos AF (1992) Stoichiometric variations of N, P, C and $\mathrm{O}_{2}$ during a Gymnodinium catenatum red tide and their interpretation. Mar Ecol Prog Ser 87:123-134

Fraga F, Ríos AF, Pérez, FF, Figueiras FG (1998) Theoretical limits of oxygen:carbon and oxygen:nitrogen ratios during photosynthesis and mineralization of organic matter in the sea. Sci Mar 62(1/2):161-168

Goldman JC, Hansell DA, Dennett MR (1992) Chemical characterization of three large oceanic diatoms: potential impact on water column chemistry. Mar Ecol Prog Ser 88: $257-270$

Hansen HP, Grasshoff K (1983) Automated chemical analysis. In: Grasshoff K, Ehrhardt M, Kremlig K (eds) Methods of seawater analysis. Verlag Chemie, Weinheim

Holligan PM (1978) Patchiness in subsurface phytoplankton populations in the northwest European continental shelf. In: Steele JH (ed) Spatial patterns in plankton communities. Plenum Press, New York, p 222-238

Kester DR (1975) Dissolved gases other than $\mathrm{CO}_{2}$. In: Riley JP, Skirrow G (eds) Chemical oceanography, Vol 1, 2nd edn. Academic Press, London, p 497-547

Kudela RM, Cochlan WP, Dugdale RC (1997) Carbon and nitrogen uptake response to light by phytoplankton during an upwelling event. J Plankton Res 19(5):609-630

Lancelot C, Mathot S (1985) Biochemical fractionation of primary production by phytoplankton in Belgian coastal waters during short- and long-term incubations with ${ }^{14} \mathrm{C}$ bicarbonate. Mar Biol 86:219-226

Lavín A, Díaz G, Cabanas JM, Casas G (1990) Afloramiento en el noroeste de la península Ibérica. Indices de afloramiento para el punto $43^{\circ} \mathrm{N} 11^{\circ} \mathrm{W}$. Periodo $1966-1989$. Inf Tec Inst Esp Oceanogr 91:40

Lewis MR, Harrison WG, Oakey NS, Herbert D, Platt T (1986) Vertical nitrate fluxes in the oligotrophic ocean. Science $234: 870-873$

Mehrbach $\mathrm{C}$, Culberson $\mathrm{CH}$, Hawley JE, Pytkowicz RM (1973) Measurements of the apparent dissociation constant of carbonic acid in seawater at atmospheric pressure. Limnol Ocean 18:897-907

Moore JK, Villareal TA (1996) Buoyancy and growth characteristics of three positively buoyant marine diatoms. Mar Ecol Prog Ser 132:203-212

Mouriño C. Fraga F (1985) Determinación de nitratos en agua de mar. Invest Pesq 49:81-96

Mouriño C, Pérez FF, Ríos AF, Manríquez M. Estrada M, Marrasé C, Prego R, Fraga F (1985) Campaña 'Galicia VIII' datos basicos. Datos Informativos Inst Inv Pesq 13:108

Passow U (1991) Vertical migration of Conyaulax catenata and Mesodinium rubrum, Mar Biol 1 10:455-463

Pérez FF. Fraga F (1987a) The pH measurements in seawater on NBS scale. Mar Chem 21:315-327

Pérez FF, Fraga F (1987b) A precise and rapid analytical procedure for alkalinity determination. Mar Chem 21:169-162

Pérez FF, Estrada M, Salat J (1986) Sistema del carbónico, oxígeno y nutnentes en el Mediterráneo occidental. Invest Pesq 50(3):333-351

Probyn TA, Waldron HN, Searson S, Owens NJP (1996) Diel variability in nitrogenous nutrient uptake at photic and subphotic depths. J Plankton Res 18(11):2063-2079 
Raven JA, Richardson K (1984) Dinophyte flagella: a costbenefit analysis. New Phytol, 98:259-276

Redfield AC, Ketchum BH, Richards FA (1963) The influence of organisms on the composition of sea-water. In: Hill NH (ed) The sea, Vol 2. Wiley, New York, p 26-77

Richardson TL, Cullen JJ (1995) Changes in buoyancy and chemical composition during growth of a coastal marine diatom: ecological and biogeochemical consequences. Mar Ecol Prog Ser 128:77-90

Richardson TL, Ciotti AM, Cullen JJ, Villareal TA (1996) Physiological and optical properties of Rhizosolenia formosa (Bacillariophyceae) in the context of open-ocean vertical migration. J Phycol 32:741-757

Richardson TL, Cullen JJ, Kelley DE, Lewis MR (1998) Potential contributions of vertically migrating Rhizosolenia to nutrient cycling and new production in the open ocean. J Plankton Res 20(2):219-241

Ríos AF, Rellán T (1998) pH and alkalinity measurements. In: Recueil de données par Le Groupe CITHER-3, Vol 3. Laboratoire de Physique des Océans (98-03), Brest, p 72-80

Ríos AF, Rosón G (1996) $\mathrm{pH}$ and alkalinity measurements. In: Recueil de données par Le Groupe CITHER-2, Vol 2. Laboratoire de Physique des Océans (98-02), Brest, p 64-70

Ríos AF, Fraga F, Figueiras FG, Pérez FF (1998) A modelling approach to the Redfield ratio deviations in the ocean. Sci Mar 62(1-2):169-176

Sambrotto RN, Savidge G, Robinson C, Boyd P, Takahashi T, Karl DM, Langdon C, Chipman D, Marra J, Codispoti L (1993) Elevated consumption of carbon relative to nitrogen in the surface ocean. Nature 363:248-250

Smith WO, Barber RT (1979) A carbon budget for the autotrophic cialite Mesodinium rubrum. J Phycol 15: $27-33$

Strickland JDH, Parsons TR (1968) A practical handbook of

Editorial responsibility: Otto Kinne (Editor),

Oldendorf/Luhe, Germany seawater analysis. Bull Fish Res Board Can 167

Takahashi T, Broecker WS, Langer S (1985) Redfield ratio based on chemical data from isopycnal surfaces. J Geophys Res 90:6907-6924

Villareal TA, Carpenter EJ (1994) Chemical composition and photosynthetic characteristics of Ethmodiscus rex (Bacillariophyceae): evidence for vertical migration. J Phycol 30: $1-8$

Villareal TA, Altabet MA, Culver-Rymsza K (1993) Nitrogen transport by vertically migrating diatom mats in the North Pacific Ocean. Nature 363:709-712

Villareal TA, Woods S, Moore JK, Culver-Rymsza K (1996) Vertical migration of Rhizosolenia mats and their significance to $\mathrm{NO}_{3}^{-}$fluxes in the central North Pacific gyre. J Plankton Res 18(7):1103-1121

Villareal TA, Pilskaln C, Brzezinski M, Lipschultz F, Dennett M, Gardner GB (1999) Upward transport of oceanic nitrate by migrating diatom mats. Nature 397:423-425

Villarino ML, Figueiras FG, Jones KJ, Alvarez-Salgado XA, Richard J, Edwards A (1995) Evidence of diel vertical migration of red tide species in nature. Mar Biol 123: $607-617$

Walsh JJ (1996) Nitrogen fixation within a tropical upwelling ecosystem: evidence for a Redfield budget of carbon/nitrogen cycling by the total phytoplankton community. J Geophys Res 101(C9):20607-20616

Weiss RF (1974) Carbon dioxide in water and seawater: the solubility of a non-ideal gas. Mar Chem 2:203-215

Wilkerson FP, Grunseich G (1990) Formation of blooms by the symbiotic ciliate Mesodinium rubrum: the significance of nitrogen uptake. J Plankton Res 12(5):973-989

Yentsch CS, Menzel DW (1963) A method for the determination of phytoplankton chlorophyll and pheophytin by fluorescence. Deep-Sea Res 10:221-231

Submitted: October 7, 1998; Accepted: May 20, 1999

Proofs received from author(s): November 1, 1999 